\title{
Constrained nearshore larval distributions and thermal stratification
}

\author{
Malloree L. Hagerty ${ }^{1, *}$, Nathalie Reyns ${ }^{1}$, Jesús Pineda ${ }^{2}$ \\ ${ }^{1}$ Environmental and Ocean Sciences Department, University of San Diego, San Diego, California 92110, USA \\ ${ }^{2}$ Biology Department, Woods Hole Oceanographic Institution, Woods Hole, Massachusetts 02543, USA
}

\begin{abstract}
Vertical and cross-shore distributions and abundances of shallow-water barnacle larvae were characterized in La Jolla, southern California (USA), during a 2 yr period. Five stations located within $1 \mathrm{~km}$ of shore and ranging from 4-12 $\mathrm{m}$ water depths were sampled intensively in $2 \mathrm{~m}$ depth intervals during 27 cruises throughout spring-summer (April-July) and fall-winter (October-December) of 2014 and 2015. Larval abundances significantly decreased from 2014 to 2015, which could be related to the arrival of a warm-water anomaly (the so-called 'Blob') in 2014 and El Niño conditions in 2015. Despite the presence of these large-scale regional disturbances, vertical and cross-shore larval distributions were consistent throughout the 2 yr study period. Early-stage nauplii and Chthamalus fissus cyprids tracked bottom depth, and cyprids were on average deeper than nauplii. Vertical distributions were not related to the mid-depth of the thermocline or thermal stratification. Early-stage nauplii had a broader cross-shore distribution than cyprids, which were concentrated at inshore stations. Nearshore cyprid concentration had a positive relationship with thermal stratification, and the center of distribution of cyprids was farther offshore during fall-winter when stratification decreased. These results suggest that thermal stratification elicits enhanced behavioral control of cyprids to remain close to shore and reach the adult habitat.
\end{abstract}

KEY WORDS: Barnacle larvae $\cdot$ Chthamalus fissus $\cdot$ Early-stage nauplii · Cyprids · Hydrographic and hydrodynamic conditions

\section{INTRODUCTION}

Larval transport, defined as the mean horizontal translocation of larvae between one point and another along a specified spatial dimension (Pineda \& Reyns 2018), is crucial to understanding population connectivity in marine environments, with implications for conservation, genetic diversity, and fisheries management (reviewed by Cowen et al. 2007). The biological and physical mechanisms of larval transport in the ocean are multifaceted and complex; they involve physical processes that have the potential to transport larvae, as well as behavioral responses to environmental cues that remain poorly understood (reviewed by Metaxas 2001, Epifanio \& Cohen 2016, Pineda \&

${ }^{*}$ Corresponding author: mhagerty@sandiego.edu

$\S_{\text {Corrections were made after publication. For details see }}$ www.int-res.com/articles/meps_oa/m627p233.pdf This updated version: September 26, 2019
Reyns 2018), particularly in nearshore environments where sampling is challenged by the complexities of shallow bathymetric features (Davies 1977). A greater understanding of larval transport processes in nearshore systems has become increasingly essential, as studies reveal that larvae exhibit more constrained distributions than originally assumed (Tapia \& Pineda 2007, Morgan et al. 2009, Shanks \& Shearman 2009, Weidberg et al. 2015, reviewed by Pineda \& Reyns 2018). Larval transport and dispersal mechanisms can inform the designation of marine reserves and marine protected areas (Shanks et al. 2003), and we cannot effectively manage these regions without a more complete grasp on dominant transport mechanisms and larval behavior in waters adjacent to the coast.

() The authors 2018. Open Access under Creative Commons by Attribution Licence. Use, distribution and reproduction are unrestricted. Authors and original publication must be credited.

Publisher: Inter-Research · www.int-res.com 
The dispersal of intertidal organisms, such as barnacles, is carried out in the nearshore environment where physical processes are highly variable (Morgan \& Fisher 2010, Bonicelli et al. 2016). Barnacles transition through 6 naupliar stages and 1 cyprid stage, typically during a 2-5 wk pelagic larval duration (Walley \& Rees 1969). Cyprids are especially interesting because to complete their life cycle they must return to the intertidal zone to find suitable habitats and settle before metamorphosis into juveniles. Larvae can alter their behavior to move into different depths, thus controlling their cross-shore movements through exposure to varying currents (Metaxas 2001, Tapia et al. 2010, Pineda \& Reyns 2018). Cues that might be used to make vertical changes in distribution include temperature. For example, gastropods, bivalves, and polychaetes in St. George's Bay, Nova Scotia, Canada, remained below the thermocline and pycnocline, and variations in their abundances were associated with temperature (Lloyd et al. 2012). Strong thermoclines can also restrict vertical distributions. Larval sea scallops were limited to bottom depths during a laboratory study when the water column was stratified (Daigle \& Metaxas 2011), and were more aggregated when thermal stratification was higher at Georges Bank, Massachusetts, USA (Tremblay \& Sinclair 1990). Changes in settlement of Chthamalus fissus barnacles were positively correlated with changes in stratification in La Jolla, California, USA, and there were significantly more settlers at this site than at a lesserstratified location in northern Baja California (Pineda \& López 2002). Stratification is correlated with shear and internal motions, and flows that reverse with depth are more likely to occur during highly stratified conditions (Winant \& Bratkovich 1981). Stronger stratification may increase local retention of larvae that exploit more vertically sheared flows (Pineda \& Reyns 2018).

Larvae also undergo ontogenetic vertical migrations (Paris \& Cowen 2004, Butler et al. 2011). Older damselfish larvae off the west coast of Barbados migrated vertically to remain within deeper, onshore flowing currents and were consequently retained near their natal source (Paris \& Cowen 2004). Early-stage larval spiny lobsters are positively phototactic, but this behavior diminished with age during laboratory tests (Butler et al. 2011). Dispersal simulations based on observed depth distributions revealed that twice as many larvae would successfully recruit to nurseries if they displayed ontogenetic vertical migration when compared with passive dispersers (Butler et al. 2011).
Additionally, larvae can respond to and accumulate in horizontal convergent flow (Pineda 1999, Shanks \& Shearman 2009, Ryan et al. 2014). Barnacle cyprids respond to downwelling by swimming up in laboratory experiments (DiBacco et al. 2011), and this may be the mechanism that enhanced their concentration in internal bore warm fronts off the coast of southern California (Pineda 1999). An autonomous underwater vehicle (AUV) in Monterey Bay, California, sampled increased larval concentrations when frontal gradients were strongest and upwelling anomalies persisted (Ryan et al. 2014). This AUV study also found high abundances of larvae near the seafloor, assumed to result from accumulation in a frontal convergence zone due to swimming behavior and downwelling.

Larval supply to the intertidal can also be related to wave height; a study in southeastern Australia reported more barnacle cyprids arriving to shore when wave height was high (Jeffery \& Underwood 2000), and a study in California and Oregon observed barnacle settlement when waves increased (Shanks et al. 2010). However, Pfaff et al. (2015) reported that swell height off the west coast of southern Africa facilitated delivery of mussel larvae, but not barnacle larvae. Onshore transport of barnacles occurred during downwelling, and settlement coincided with low swell, upwelling, and spring tides, suggesting that internal tides are associated with transport of larval barnacles to shore (Pfaff et al. 2015). Thus, varying hydrographic and hydrodynamic conditions can impact larvae, and understanding the vertical distribution of larvae in relation to such conditions is critical to determining larval transport and dispersal processes (discussed by Pineda \& Reyns 2018). Given the recent findings on larval distributions constrained close to shore, studies need to resolve these distributions in the very nearshore.

In this study, we conducted fine-scale, high-repetition plankton collections to resolve barnacle larval distributions. Vertical sampling in stratified, $2 \mathrm{~m}$ depth intervals throughout the water column was coupled with high spatial resolution sampling at 5 cross-shore locations within $1 \mathrm{~km}$ from the intertidal, commensurate with physical measurements in the nearshore. We hypothesized that larval barnacle abundance and distributions would vary with ontogenetic stage, temperature and thermal stratification, currents, and wave height. Specifically, we addressed the following questions: What are the finescale patterns of vertical and cross-shore barnacle larval distributions in the nearshore? Do nauplii and cyprids display different distribution patterns? Are 
patterns in larval distribution related to hydrographic and hydrodynamic conditions?

\section{MATERIALS AND METHODS}

\section{Study site and system}

This study was conducted offshore of Bird Rock, La Jolla, California, and included 5 sampling stations located at distances of 280,460,640,820, and $1000 \mathrm{~m}$ from shore at water depths of 4,6, 8, 10, and $12 \mathrm{~m}$, respectively (Fig. 1). We selected this study area as the shoreline provides extensive adult barnacle habitat, particularly for the abundant Chthamalus fissus, and larvae of the predominant barnacle species in the region have been observed in surrounding nearshore waters (C. fissus, Balanus glandula, Megabalanus californicus, and Pollicipes polymerus; Hoffman 1989, Pineda 1991, 1999, Pineda \& López 2002, Tapia \& Pineda 2007, Tapia et al. 2010). Further, the shelf bathymetry is simple. Sampling occurred during April-July (hereafter spring-summer) and October-December (hereafter fall-winter) in 2014 and 2015, and consisted of plankton sampling cruises as well as hydrographic and hydrodynamic measurements obtained from instrument deployments (see

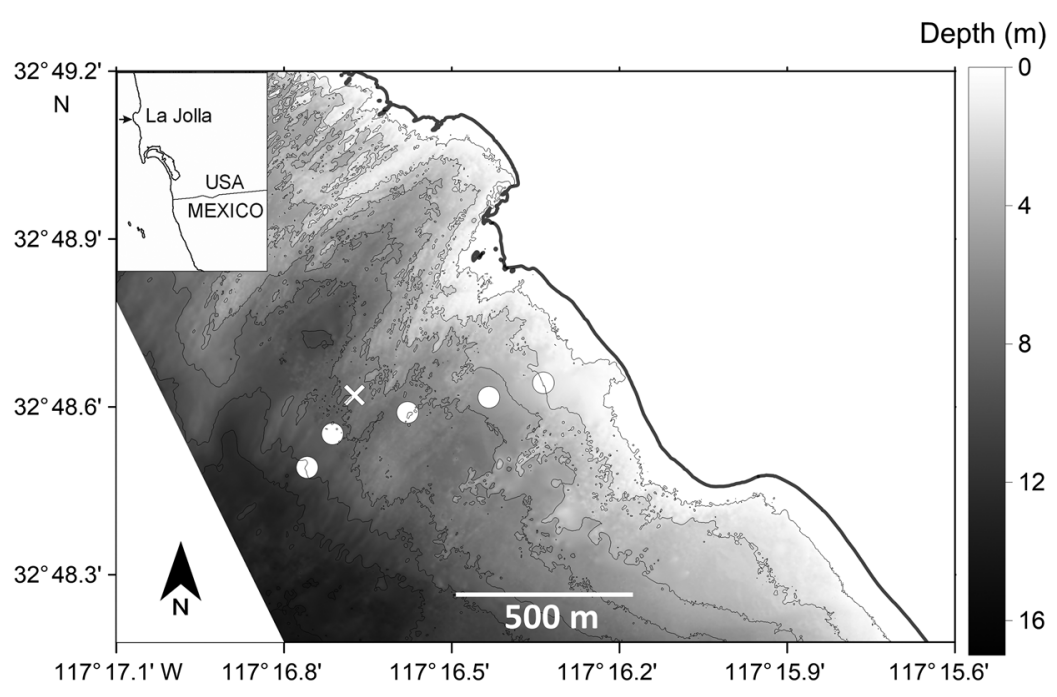

Fig. 1. Study site offshore of Bird Rock, La Jolla, southern California, USA. Circles indicate plankton sampling stations at 280, 460,640, 820, and $1000 \mathrm{~m}$ from shore at a bottom depth of 4,6, 8, 10, and $12 \mathrm{~m}$, respectively, moving offshore from right to left. X indicates the location of the acoustic Doppler current profiler (ADCP) to measure currents, and pressure sensor to measure waves. Subsurface temperature mooring was deployed $\sim 10 \mathrm{~m}$ from the ADCP. Bottom depth contours every $2 \mathrm{~m}$ relative to Mean Lower Low Water (MLLW), with the shallowest contour at MLLW. Lidar data from the 2013 NOAA Coastal California TopoBathy Merge Project, https://coast.noaa.gov/dataviewer/\#/ lidar/search/where:ID=2612 below). Sampling periods were chosen to encompass times of barnacle settlement (Hines 1976, 1978, Pineda 1994), and during expected seasonal contrasts in hydrographic conditions: thermal stratification is greater in spring-summer than in fall-winter when the onset of cooling and increased storm activity enhances water column mixing (Winant \& Bratkovich 1981, Palacios et al. 2004).

\section{Plankton sampling}

Plankton sampling was conducted using a $7.6 \mathrm{~m}$ boat with a davit, and included 27 cruises in total: 9 in spring-summer (May-July) and 6 in fall-winter (October-December) of 2014, 8 in spring-summer (April-July) and 4 in fall-winter (October-December) of 2015. During each cruise, plankton samples were collected using an Ebara 50DWXU6.4S Dominator submersible semivortex pump to filter $2 \mathrm{~m}^{3}$ of seawater in discrete $2 \mathrm{~m}$ depth bins, while continuously oscillating the pump within the $2 \mathrm{~m}$ sampling interval. Sampling extended from the surface to the bottom at each of the 5 stations (20 samples cruise $^{-1}$ with a few exceptions where sea state conditions or equipment failure interrupted sampling). Seawater was filtered through a $118 \mu \mathrm{m}$ mesh net to capture barnacle larval stages $(C$. fissus larvae range in size from $\sim 124 \mu \mathrm{m}$ long $\times 206 \mu \mathrm{m}$ wide as stage I nauplii through $\sim 493 \mu \mathrm{m}$ long $\times 246 \mu \mathrm{m}$ wide at the cyprid stage; Miller et al. 1989), and samples were immediately preserved in $100 \%$ ethanol.

Plankton samples were sorted using a dissecting microscope, and barnacle larvae were enumerated. Nauplii were staged as early (II-III) or late (IV-VI) stage, and cyprids were classified to species based on published morphological descriptions (e.g. Lewis 1975, Branscomb \& Vedder 1982, Brown \& Roughgarden 1985, Miller et al. 1989, Miller \& Roughgarden 1994, Shanks 2001). Species identifications were confirmed using molecular tools (M. Hagerty et al. unpubl. data). Earlystage nauplii could not be identified to species due to morphological degradation, but late-stage nauplii were classified as C. fissus or 'other' due to their distinct size and shape. C. fissus is the most abundant barnacle in the region, 
and most early-stage nauplii collected likely belong to this species. Stage I nauplii were not present in our samples, presumably due to the rapid transition to stage II after hatching (Brown \& Roughgarden 1985, Miller et al. 1989).

\section{Larval distributions}

We described the vertical and horizontal larval distribution patterns of the most abundant barnacle species in our samples; thus, detailed analyses were conducted for early-stage barnacle nauplii (>98\% of the total nauplii collected; Table 1) and C. fissus cyprids, which comprised $>60 \%$ of the barnacle cyprids (Table 2). To characterize vertical distribution of larval stages, mean depth distributions (MDDs; Tapia et al. 2010) were calculated for each station according to the following equation:

MDD $=\Sigma\left(\right.$ no. $\mathrm{m}^{-3}$ in sample interval $\times$ mean depth of sample interval) $/ \Sigma$ (no. $\mathrm{m}^{-3}$ at station)

Table 1. Nauplii concentration summaries for all sampling periods: 2014 spring-summer ( $\mathrm{N}=149$ samples), 2014 fall-winter ( $N=108), 2015$ spring-summer $(N=136), 2015$ fall-winter $(N=78)$

\begin{tabular}{|c|c|c|c|c|}
\hline Nauplii & $\begin{array}{l}2014 \text { spring- } \\
\text { summer }\end{array}$ & $\begin{array}{l}2014 \text { fall- } \\
\text { winter }\end{array}$ & $\begin{array}{l}2015 \text { spring- } \\
\text { summer }\end{array}$ & $\begin{array}{l}2015 \text { fall- } \\
\text { winter }\end{array}$ \\
\hline \multicolumn{5}{|c|}{ Maximum concentration (no. larvae $\mathrm{m}^{-3}$ ) } \\
\hline Early stage & 2104.15 & 165.90 & 135.92 & 651.63 \\
\hline Late-stage Chthamalus fissus & 0 & 5.99 & 11.99 & 3.99 \\
\hline Late-stage other & 4.04 & 0 & 1.99 & 5.99 \\
\hline \multicolumn{5}{|c|}{ Mean concentration (no. larvae $\mathrm{m}^{-3}$ ) $\pm \mathrm{SE}$} \\
\hline Early stage & $91.23 \pm 21.66$ & $16.41 \pm 3.04$ & $9.81 \pm 1.73$ & $50.49 \pm 13.45$ \\
\hline Late-stage Chthamalus fissus & 0 & $0.09 \pm 0.06$ & $0.15 \pm 0.09$ & $0.36 \pm 0.11$ \\
\hline Late-stage other & $0.10 \pm 0.04$ & 0 & $0.02 \pm 0.02$ & $0.17 \pm 0.09$ \\
\hline \multicolumn{5}{|l|}{ Percent of total nauplii (\%) } \\
\hline Early stage & 99.90 & 99.44 & 98.34 & 98.97 \\
\hline Late-stage Chthamalus fissus & 0 & 0.56 & 1.47 & 0.70 \\
\hline Late-stage other & 0.10 & 0 & 0.18 & 0.33 \\
\hline
\end{tabular}

Table 2. Cyprid concentration summaries for all sampling periods; sample sizes are given in Table 1 legend

\begin{tabular}{|c|c|c|c|c|}
\hline Cyprids & $\begin{array}{l}2014 \text { spring- } \\
\text { summer }\end{array}$ & $\begin{array}{l}2014 \text { fall- } \\
\text { winter }\end{array}$ & $\begin{array}{l}2015 \text { spring- } \\
\text { summer }\end{array}$ & $\begin{array}{l}2015 \text { fall- } \\
\text { winter }\end{array}$ \\
\hline \multicolumn{5}{|c|}{ Maximum concentration (no. larvae $\mathrm{m}^{-3}$ ) } \\
\hline Chthamalus fissus & 427.76 & 116.93 & 21.98 & 85.95 \\
\hline Balanus glandula & 9.99 & 1.09 & 3.99 & 3.99 \\
\hline Pollicipes polymerus & 11.99 & 17.98 & 13.14 & 7.99 \\
\hline Tetraclita rubescens & 19.98 & 1.99 & 3.99 & 0 \\
\hline Megabalanus californicus & 9.99 & 1.99 & 14.99 & 3.99 \\
\hline Balanus trigonus & 11.99 & 0 & 0.49 & 3.99 \\
\hline Unknown & 5.99 & 0 & 3.99 & 0 \\
\hline \multicolumn{5}{|c|}{ Mean concentration (no. larvae $\mathrm{m}^{-3}$ ) $\pm \mathrm{SE}$} \\
\hline Chthamalus fissus & $20.48 \pm 4.34$ & $4.12 \pm 1.25$ & $1.86 \pm 0.32$ & $4.76 \pm 1.48$ \\
\hline Balanus glandula & $0.58 \pm 0.13$ & $0.01 \pm 0.01$ & $0.08 \pm 0.04$ & $0.16 \pm 0.08$ \\
\hline Pollicipes polymerus & $0.37 \pm 0.11$ & $0.24 \pm 0.17$ & $0.52 \pm 0.15$ & $0.36 \pm 0.14$ \\
\hline Tetraclita rubescens & $0.75 \pm 0.21$ & $0.04 \pm 0.03$ & $0.06 \pm 0.04$ & 0 \\
\hline Megabalanus californicus & $0.67 \pm 0.14$ & $0.04 \pm 0.03$ & $0.49 \pm 0.17$ & $0.08 \pm 0.06$ \\
\hline Balanus trigonus & $0.11 \pm 0.08$ & 0 & $0.01 \pm 0.01$ & $0.16 \pm 0.08$ \\
\hline Unknown & $0.26 \pm 0.07$ & 0 & $0.06 \pm 0.04$ & 0 \\
\hline \multicolumn{5}{|l|}{ Percent of total cyprids (\%) } \\
\hline Chthamalus fissus & 88.11 & 92.56 & 60.51 & 86.29 \\
\hline Balanus glandula & 2.51 & 0.23 & 2.63 & 2.90 \\
\hline Pollicipes polymerus & 1.61 & 5.46 & 16.77 & 6.51 \\
\hline Tetraclita rubescens & 3.21 & 0.82 & 1.91 & 0 \\
\hline Megabalanus californicus & 2.87 & 0.94 & 16.02 & 1.39 \\
\hline Balanus trigonus & 0.46 & 0 & 0.24 & 2.90 \\
\hline Unknown & 1.12 & 0 & 1.91 & 0 \\
\hline
\end{tabular}


We used a 1-factor analysis of variance (ANOVA) to test for differences in MDD of nauplii and cyprids between sampling periods (spring-summer 2014, fall-winter 2014, spring-summer 2015, fall-winter 2015). ANOVA assumptions of normality, homoscedasticity, and absence of collinearity were met. A paired $t$-test was also used to compare MDDs of early-stage nauplii to $C$. fissus cyprids.

To account for the vertical dilution of larvae when comparing larval concentrations at stations of varying depths, total larval concentration (no. $\mathrm{m}^{-3}$ ) at each station was multiplied by station depth to standardize samples to larval density (no. $\mathrm{m}^{-2}$ ). To determine if larval abundances varied across stations, we calculated the proportion of total early-stage nauplii and $C$. fissus cyprids at each station on a given cruise date, and used a 2-factor ANOVA to test for differences in larval proportions between stations and sampling periods (spring-summer vs. fall-winter). Additionally, we calculated the mean distance from shore (MDS; referred to as 'average distance offshore' in Shanks \& Shearman 2009) of the larval stages for each cruise:

MDS $=\Sigma\left(\right.$ no. $\mathrm{m}^{-2}$ at a given station $\times$ distance from shore of station) $/ \Sigma$ (no. $\mathrm{m}^{-2}$ at all stations)

A Student's $t$-test was used to compare MDS measurements of early-stage nauplii and C. fissus cyprids. Data were log-transformed to meet the assumption of equal variances. Finally, we developed a constrained-distribution index (CDI) that considered both the influence of larval proportion and distance from shore to further investigate cyprid distribution patterns. The CDI was only calculated for cruise dates where all 5 stations were sampled. First, larval proportion anomalies were calculated for C. fissus cyprids at each station as (the proportion of $C$. fissus cyprids at each station on a given cruise date) - (the average proportion of $C$. fissus cyprids at each station for all cruises). Then, for each cruise date, the CDI was calculated as:

$\mathrm{CDI}=\Sigma$ (larval proportion anomalies at stations 280 and $460 \mathrm{~m}$ from shore) $-\Sigma$ (larval proportion anomalies at stations 640,820 , and $1000 \mathrm{~m}$ from shore) (3)

Thus, the resulting index value is positive when cyprid densities are higher than average at the 2 inshore stations, and negative if cyprid densities are lower than average at the 2 inshore stations. The CDI is simply an anomaly from a canonical distribution that can be used to test for hydrographic or hydrodynamic conditions under which cross-shore larval distribution patterns change. We chose the 2 inshore stations as the basis for the index, because cyprid MDS (overall mean $=531.19 \mathrm{~m}$, median $=521.34 \mathrm{~m}$ ) was located between the stations 460 (6 m depth) and 640 (8 $\mathrm{m}$ depth) $\mathrm{m}$ from shore.

\section{Temperature, currents, and pressure}

A CastAway-CTD (SonTek) was used to obtain temperature and depth measurements before and after plankton pumping at each station. Salinity was not considered in this study because stratification at our study site is due to vertical differences in temperature rather than salinity (Hagerty 2017). Depthaveraged temperature, mid-depth of the thermocline, and thermal stratification were calculated for each station. The mid-depth of the thermocline was determined as the depth at which the greatest change in temperature occurred for a given CTD cast. Thermal stratification was defined as change in temperature $\mathrm{m}^{-1}\left(\Delta \mathrm{T}^{\circ} \mathrm{C} \mathrm{m}^{-1}\right)$ :

Thermal stratification $=($ temperature at surface temperature at bottom) / (depth of bottom temperature - depth of surface temperature)

Additionally, thermal stratification within our study site was calculated by averaging thermal stratification at the 3 offshore stations $(640,820$, and $1000 \mathrm{~m}$ from shore with bottom depths of 8,10 , and $12 \mathrm{~m}$, respectively) for each cruise, hereafter referred to as zonal stratification. These stations were selected to represent zonal thermal stratification as they most frequently exhibited the highest stratification at our site.

A $1200 \mathrm{kHz}$ RDI acoustic Doppler current profiler (ADCP) was deployed between the plankton sampling stations 640 (8 $\mathrm{m}$ depth) and 820 (10 $\mathrm{m}$ depth) $\mathrm{m}$ offshore (Fig. 1) during the entire duration of each sampling period to record current velocities every $2 \mathrm{~s}$ throughout the water column in $0.4 \mathrm{~m}$ depth bins. Error velocities, percent good, beam correlation, signal strength anomaly, and bin-to-bin velocity differences were all examined as part of current profile quality control. All of these, but particularly signal strength, were useful in removing times when kelp contaminated the velocity measurements. Currents were rotated to align the predominant alongshore flow with the coastline, decomposed into alongshore (positive southward) and cross-shore (positive onshore) components, and depth-averaged. Currents associated with each cruise were calculated as the average of the $24 \mathrm{~h}$ previous to the cruise end time. 
The relationship between zonal stratification and depth variability of the cross-shore currents was obtained for dates when all 5 stations were sampled. For each of these dates, current variability with depth was estimated by computing the standard deviation across depth of the hourly cross-shore currents. Twelve-hourly estimates of the standard deviation were then averaged and plotted against zonal stratification. These 12-hourly data corresponded in time to the measurements of zonal stratification during the cruise (ca. $4 \mathrm{~h}$ ) and the time preceding the cruise (ca. $8 \mathrm{~h})$.

Temperature was also concurrently measured at a subsurface mooring deployed $\sim 10 \mathrm{~m}$ from the ADCP (Fig. 1). Temperature was measured every $5 \mathrm{~s}$ with 5 SBE 56 loggers spaced $\sim 1.2 \mathrm{~m}$ apart, from 1.2 to $\sim 6.5 \mathrm{~m}$ above bottom. To illustrate patterns of variability, zonal stratification and cross-shore currents were plotted for the corresponding cruise dates with the highest and lowest stratification. Temperature and cross-shore currents were averaged for the duration of each plankton cruise (ca. 4 h) by depth bin.

A Sea-Bird Electronics Seagauge was deployed on the ADCP frame, and configured to record pressure every 3 h. Significant wave height (SWH) was calculated as $4 \times$ the square root of the sea surface spectrum between periods of 4 and $30 \mathrm{~s}$. We calculated the $24 \mathrm{~h}$ SWH average in the same way as previously described for currents.

\section{Relationships between physical variables and larvae}

Relationships between relevant physical variables (mid-depth of the thermocline, thermal stratification, zonal stratification, $24 \mathrm{~h}$ currents, and $24 \mathrm{~h} \mathrm{SWH}$ ) and larvae (larval density, MDD, MDS, and CDI) were analyzed using individual regression analyses for each physical predictor. Values are presented as mean $( \pm 1 \mathrm{SE})$ where applicable.

\section{RESULTS}

\section{Physical conditions}

Depth-averaged hourly alongshore currents were generally stronger in spring-summer (ranging from $\sim-0.16$ to $0.19 \mathrm{~m} \mathrm{~s}^{-1}$, Fig. 2A) than fall-winter (ranging from $\sim-0.20$ to $0.10 \mathrm{~m} \mathrm{~s}^{-1}$, Fig. 2B) in 2014, but stronger in fall-winter (ranging from -0.20 to 0.43 $\mathrm{m} \mathrm{s}^{-1}$, Fig. 3B) than spring-summer (ranging from
-0.20 to $0.18 \mathrm{~m} \mathrm{~s}^{-1}$, Fig. 3A) of 2015. Depth-averaged $24 \mathrm{~h}$ alongshore currents were southward (positive) on all but 7 cruise dates, ranging from -0.12 to $0.05 \mathrm{~m}$ $\mathrm{s}^{-1}$ with a mean value of $0.006( \pm 0.007) \mathrm{m} \mathrm{s}^{-1}$. Depthaveraged hourly cross-shore currents were slower than alongshore currents and comparable across the 4 sampling periods, ranging from $\sim-0.07$ to $0.02 \mathrm{~m}$ $\mathrm{s}^{-1}$ (Figs. 2C,D \& 3C,D). Depth-averaged $24 \mathrm{~h}$ crossshore currents were offshore (negative) during 15 cruises and onshore (positive) during 12 cruises, ranging from -0.02 to $0.007 \mathrm{~m} \mathrm{~s}^{-1}$ with a mean of $-0.003( \pm 0.001) \mathrm{m} \mathrm{s}^{-1}$.

SWH ranged from $\sim 0.25$ to $3 \mathrm{~m}$, and there were more peaks in SWH during fall-winter than springsummer of both years (Figs. 2E,F \& 3E,F). The largest waves during 2014 and 2015 were usually associated with southward and offshore current flows (Figs. $2 \mathrm{~A}-\mathrm{F} \& 3 \mathrm{~A}-\mathrm{F})$. The overall mean SWH for 2014 and 2015 was $0.54( \pm 0.03) \mathrm{m}$. The minimum $24 \mathrm{~h} \mathrm{SWH}$ was $0.33 \mathrm{~m}$ (in 2014 spring-summer), while the maximum was $1.03 \mathrm{~m}$ (in 2015 spring-summer).

Hourly temperature varied with depth during spring-summer sampling periods, at times decreasing $\sim 4$ to $5^{\circ} \mathrm{C}$ from surface to bottom (Figs. 2G \& $3 \mathrm{G}$ ). Temperature differences with depth decreased during fall-winter of both years (Figs. $2 \mathrm{H} \& 3 \mathrm{H}$ ). Temperatures ranged from $\sim 11$ to $23^{\circ} \mathrm{C}$ in spring-summer sampling periods, and from $\sim 16$ to $23^{\circ} \mathrm{C}$ in fall-winter, with the highest temperatures occurring at the end of spring-summer and beginning of fall-winter during 2014 and 2015. Fall-winter of 2015 was the warmest sampling period, with water temperatures rarely falling below $19^{\circ} \mathrm{C}$ (Fig. $3 \mathrm{H}$ ).

Depth-averaged temperature across stations was similar between sampling periods in 2014 (Fig. 4A), ranging from 18.2 to $19.7^{\circ} \mathrm{C}$. However, fall-winter was considerably warmer than spring-summer in 2015 (Figs. 4B \& 3G,H), with average station temperatures ranging from 16.9 to $20.8^{\circ} \mathrm{C}$. Temperature decreased with distance from shore in springsummer during both years, but this was not as obvious in 2014. In 2015, the inshore stations were noticeably warmer than the offshore stations. Cross-shelf temperature variation was minimal in fall-winter of both years. Thermal stratification increased with distance from shore during springsummer cruises and was similar across stations during fall-winter cruises, but offshore stations were still slightly more stratified (Fig. 4C,D). Stratification was markedly stronger in spring-summer than fall-winter in both 2014 and 2015, averaging $0.23( \pm 0.03)^{\circ} \mathrm{C} \mathrm{m}^{-1}$ in spring-summer and 0.06 $( \pm 0.005)^{\circ} \mathrm{C} \mathrm{m}^{-1}$ in fall-winter. 

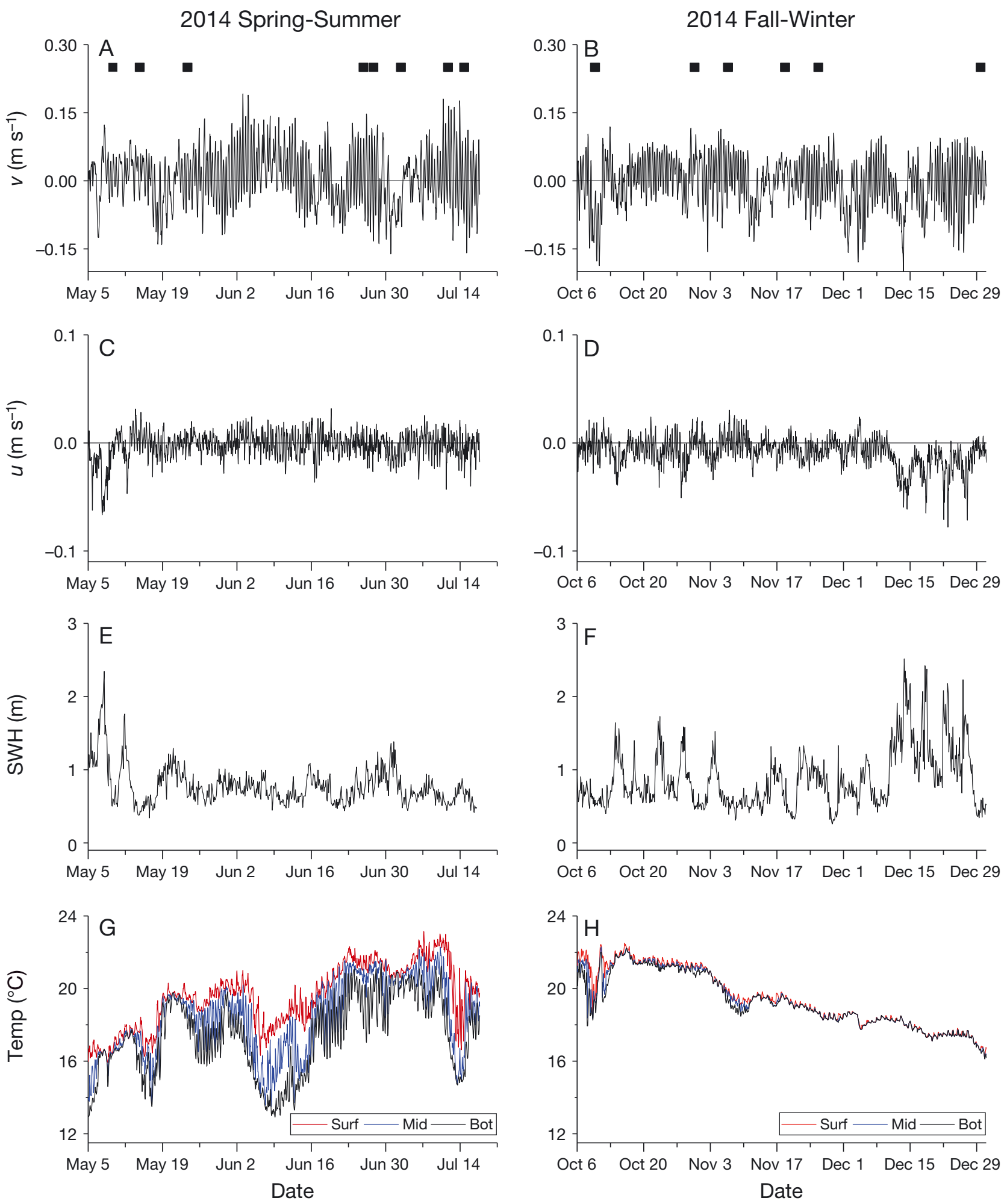

Fig. 2. Summary of hydrographic and hydrodynamic conditions in 2014. ADCP and temperature mooring deployments from spring-summer are shown in the left panels, and fall-winter in the right panels. (A,B) Depth-averaged alongshore currents (v), where positive is southward flow; $(C, D)$ depth-averaged cross-shore currents $(u)$, where positive in onshore (eastward) flow; $(\mathrm{E}, \mathrm{F})$ significant wave height $(\mathrm{SWH}) ;$ and $(\mathrm{G}, \mathrm{H})$ temperature. Surf: surface temperature at $6.5 \mathrm{~m}$ above bottom; mid: mid-depth temperature at $3.6 \mathrm{~m}$ above the bottom; bot: bottom temperature at $0.3 \mathrm{~m}$ above bottom. Black rectangles in panels A and B correspond with times of plankton sampling 

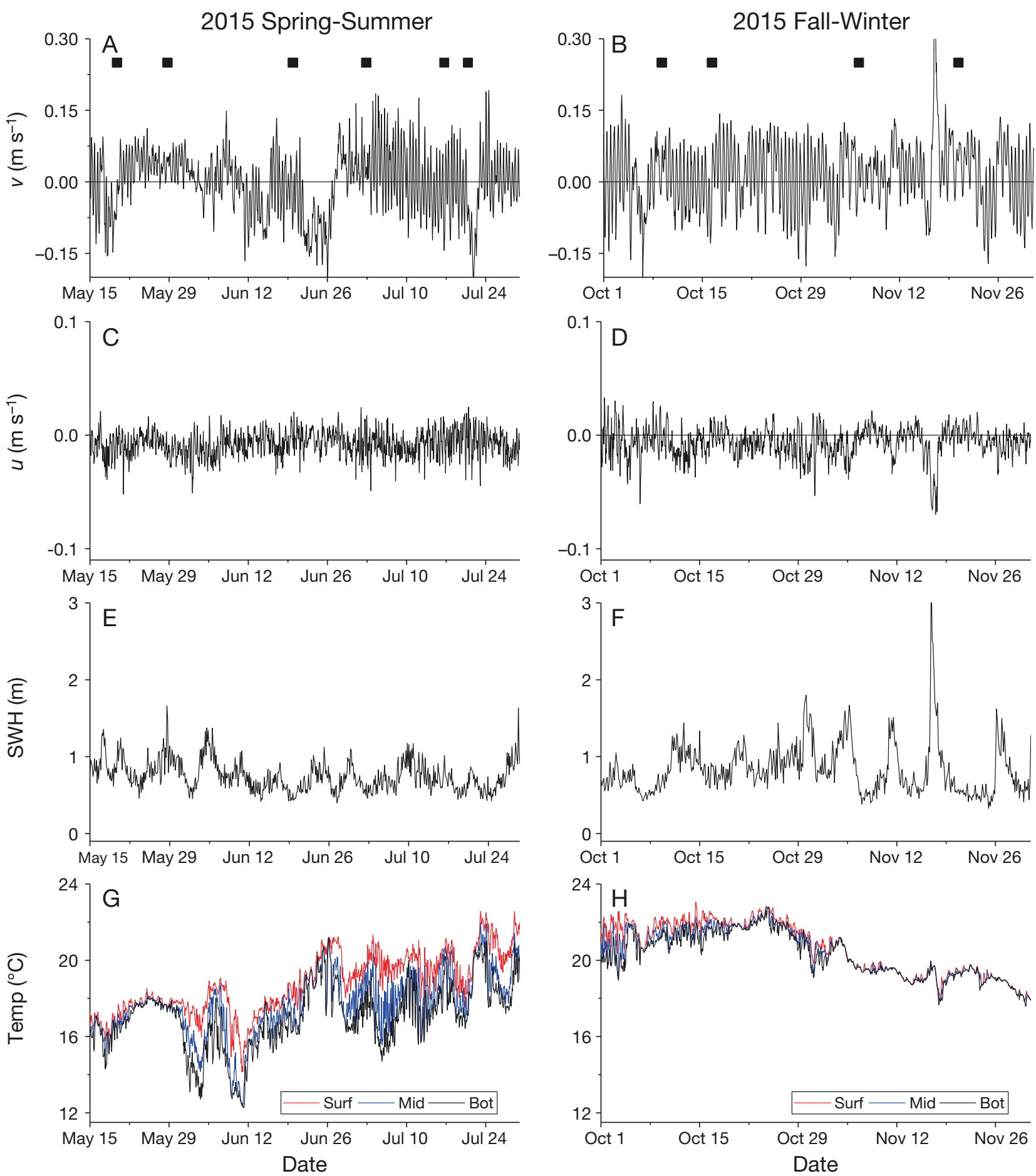

Fig. 3. Summary of hydrographic and hydrodynamic conditions in 2015. Details as in Fig. 2

\section{Stratification and vertical variability in the cross- shore currents}

The standard deviation across depth of the crossshore currents tended to be high when stratification was elevated (Fig. $5 \mathrm{~A}, \mathrm{R}^{2}=0.55576, \mathrm{p}=0.0006$ ). For example, the date with the highest zonal stratification (2 July 2015) had large variability in the surface and bottom currents, with currents that reversed with depth (Fig. 5B,C), whereas the date with the lowest stratification (6 November 2015) had smaller vertical variability in the cross-shore currents (Fig. 5D,E). 

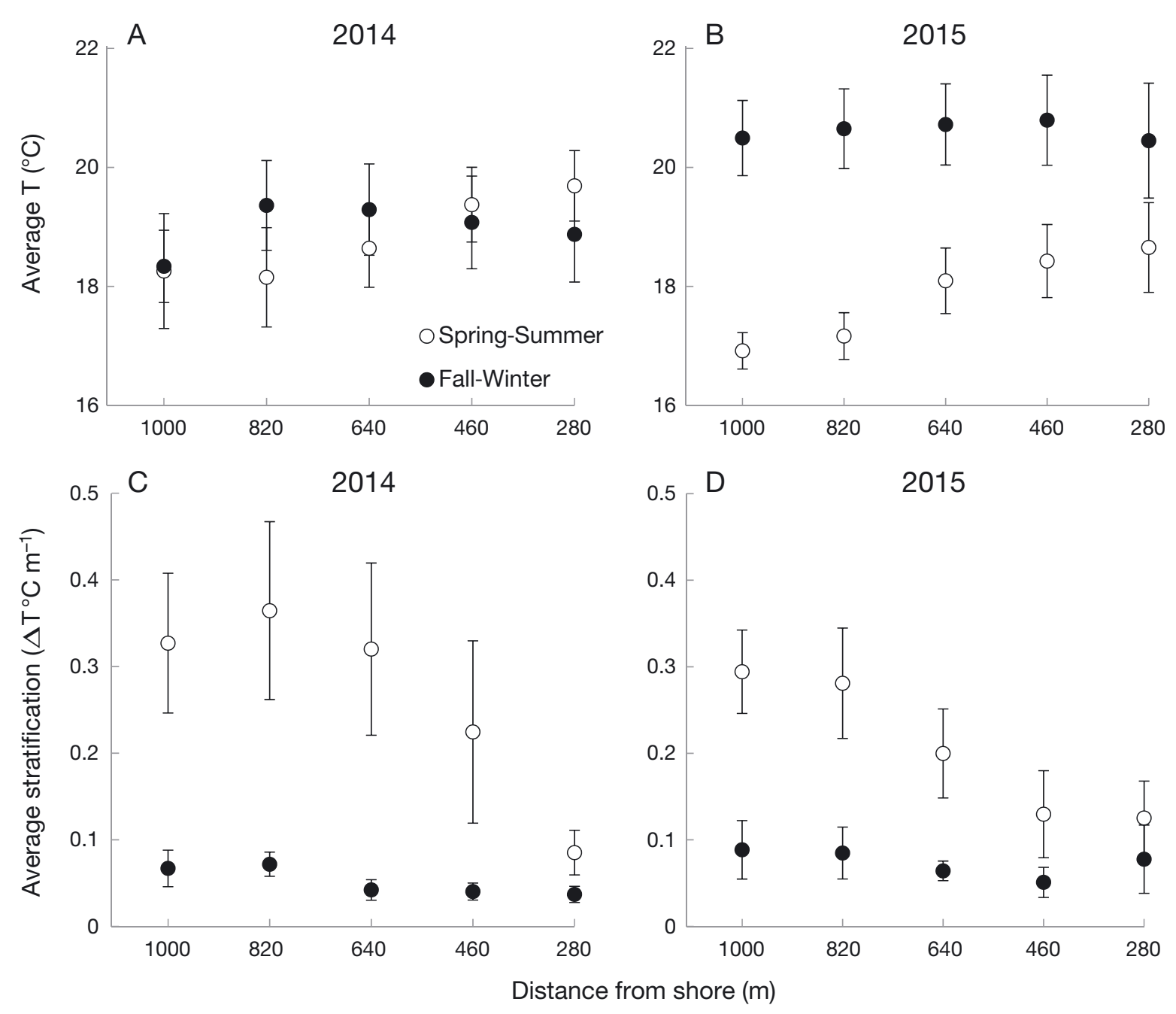

Fig. 4. Mean \pm SE $(A, B)$ depth-averaged temperature and $(C, D)$ average thermal stratification at each station during 2014 and 2015 spring-summer and fall-winter sampling periods. Note that distance from shore increases from right to left (westward) to reflect the orientation of our study site

\section{Temporal patterns of larval concentrations}

Larval concentrations were higher for nauplii than cyprids, and varied by sampling period (Tables 1 \& 2). Concentrations were higher overall in 2014 than 2015 (Table 3), and larvae were more abundant in spring-summer than fall-winter of 2014 (Tables 1 \& 2). However, larvae were more abundant in fall-winter than spring-summer of 2015 (Tables 1 \& 2). Most barnacle nauplii collected were early stage; of the late-stage nauplii, most were identified as Chthamalus fissus (Table 1). Six species of barnacle cyprids were identified at our study site, including C. fissus, Balanus glandula, Pollicipes polymerus, Tetraclita rubescens, Megabalanus californicus, and Balanus trigonus (Table 2). C. fissus comprised more than $86 \%$ of the cyprids in 2014 and fall-winter 2015, while in spring-summer 2015 C. fissus comprised only $\sim 60 \%$ of the cyprids (Table 2). Overall, average cyprid concentrations were lowest during springsummer 2015, but species were more equally represented in concentration (Table 2). Given the low concentrations of late-stage nauplii and cyprid species other than C. fissus, we did not examine the distribution patterns of scarce taxa. Hence, we analyzed the vertical and cross-shore distribution patterns of only the early-stage nauplii and C. fissus cyprids. The abundances of early-stage nauplii and C. fissus cyprids were not significantly correlated with SWH $(\mathrm{p}>0.46)$, alongshore currents $(\mathrm{p}>$ $0.67)$, cross-shore currents $(\mathrm{p}>0.33)$, or thermal stratification $(p>0.27)$ (see Hagerty 2017 for plots of these relationships). 

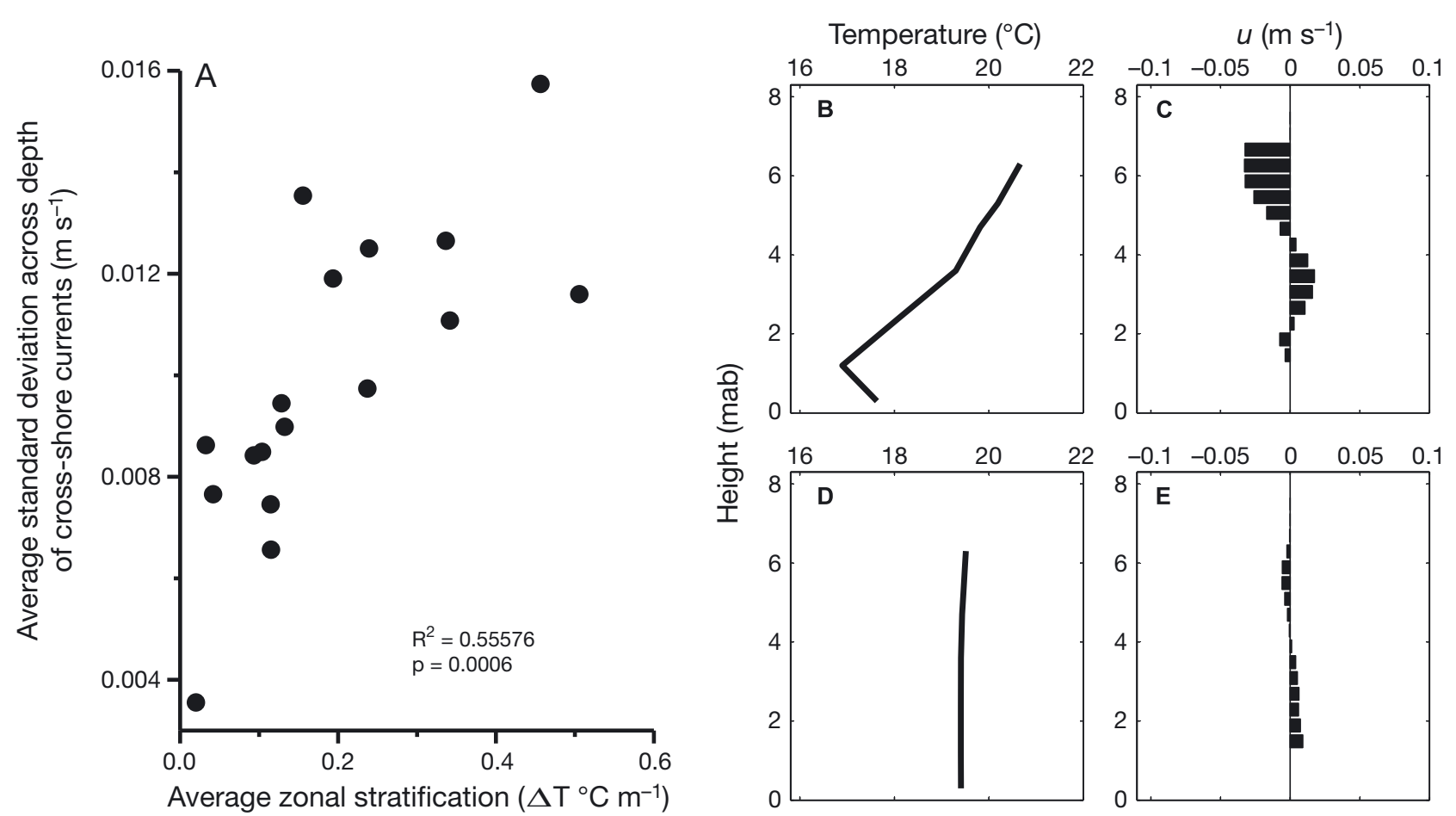

Fig. 5. (A) Average zonal stratification (average thermal stratification at stations 640, 820, and $1000 \mathrm{~m}$ from shore with bottom depths of 8,10 , and $12 \mathrm{~m}$, respectively) and variability of the cross-shore (u-component) currents with depth, for the dates when all 5 stations were sampled. Examples of depth (mab: meters above bottom) variability of stratification and cross-shore currents during the cruises with the $(B, C)$ highest (2 July 2015) and (D,E) lowest (6 November 2015) stratification

Table 3. Mean \pm SE larval concentration (no. larvae $\mathrm{m}^{-3}$ ) of nauplii and cyprids in 2014 ( $N=257$ samples) and 2015 $(\mathrm{N}=214)$

\begin{tabular}{|lrc|}
\hline & 2014 & 2015 \\
\hline Nauplii & & \\
Early stage & $59.79 \pm 12.81$ & $24.64 \pm 5.18$ \\
Late-stage Chthamalus fissus & $0.04 \pm 0.03$ & $0.22 \pm 0.07$ \\
Late-stage other & $0.06 \pm 0.02$ & $0.07 \pm 0.03$ \\
Cyprids & & \\
Chthamalus fissus & $13.61 \pm 2.62$ & $2.92 \pm 0.58$ \\
Balanus glandula & $0.34 \pm 0.08$ & $0.11 \pm 0.04$ \\
Pollicipes polymerus & $0.32 \pm 0.10$ & $0.46 \pm 0.11$ \\
Tetraclita rubescens & $0.45 \pm 0.12$ & $0.04 \pm 0.02$ \\
Megabalanus californicus & $0.40 \pm 0.08$ & $0.34 \pm 0.11$ \\
Balanus trigonus & $0.06 \pm 0.05$ & $0.06 \pm 0.03$ \\
Unknown & $0.15 \pm 0.04$ & $0.04 \pm 0.02$ \\
\hline
\end{tabular}

\section{Vertical distributions of larvae}

The MDDs of early-stage nauplii and C. fissus cyprids were deeper with increasing bottom depth and distance from shore, and cyprid MDDs were generally deeper than those of early-stage nauplii during all 4 sampling periods (Fig. 6). There was a significant difference between MDDs of early-stage nauplii and cyprids $(t=-5.547, \mathrm{p}<0.0001)$, but there were no significant differences between sampling periods for nauplii $\left(F_{1,110}=0.458, \mathrm{p}=0.499\right)$ or cyprids $\left(F_{1,97}=0.221, \mathrm{p}=0.639\right)$. The MDDs of early-stage nauplii and $C$. fissus cyprids were not correlated with the mid-depth of the thermocline $(p>0.14)$ or thermal stratification $(p>0.16)$ at any station (e.g. Fig. 6A-D), or $24 \mathrm{~h}$ alongshore $(\mathrm{p}>0.12)$ or crossshore $(p>0.22)$ currents at the station $640 \mathrm{~m}$ from shore (8 $\mathrm{m}$ depth), but early-stage nauplii MDD had a significant negative correlation with SWH (Pearson's $r=-0.39, p=0.047$ ) (see Hagerty 2017 for plots of these relationships).

\section{Cross-shore distributions of larvae}

In general, the proportion of total early-stage nauplii increased with distance from shore (Fig. 7A-D), while $C$. fissus cyprid proportions decreased with distance from shore (Fig. 7E-H). These patterns were more distinct during spring-summer periods than fall-winter periods. There were differences among stations for early-stage nauplii and $C$. fissus cyprids, with significantly more nauplii at the offshore stations and significantly more cyprids at the inshore stations (Table 4). There was also a significant differ- 


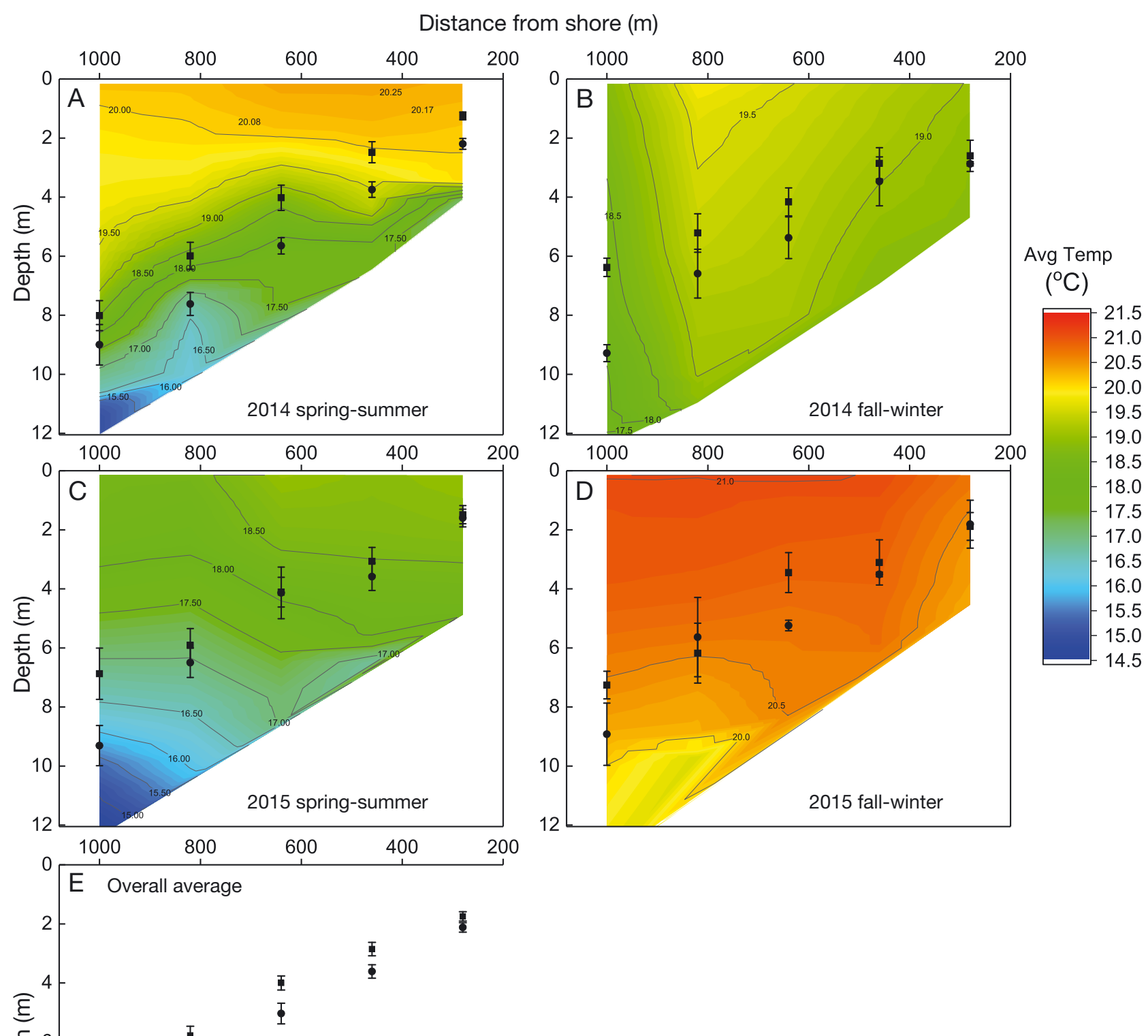

Fig. 6. Vertical distributions of barnacle larvae. Average \pm SE mean depth distributions (MDDs) of early-stage nauplii (black squares) and Chthamalus fissus cyprids (black circles) at sampling stations overlaid on average seasonal temperature contours from CTD casts during (A) 2014 spring-summer ( $\mathrm{N}=9$ cruises), (B) 2014 fall-winter ( $\mathrm{N}=6)$, (C) 2015 spring-summer ( $=8)$, and (D) 2015 fall-winter ( $\mathrm{N}$ =4). (E) Overall average MDDs during 2014-2015 ( $\mathrm{N}=27$ cruises)

ence between sampling periods for cyprids, with more cyprids at the middle station $(640 \mathrm{~m}$ offshore, $8 \mathrm{~m}$ depth) in fall-winter than spring-summer throughout the study duration (Table 4).

Early-stage nauplii were distributed farther offshore than C. fissus cyprids (MDS was significantly greater: $t=5.350, \mathrm{p}<0.0001$; Fig. 8). Additionally, cyprids were closer to shore in spring-summer than fall-winter (comparing minimum and median MDS values); however, their distributions were variable. The CDI revealed that cyprid densities were higher than average (i.e. CDI $>0$ ) at the 2 inshore stations during 5 of the 17 cruises when all 5 stations were sampled (Fig. 9B). Four of these 5 cruises were in spring-summer (2 in 2014, 2 in 2015), and 1 was in 2015 fall-winter. The highest CDI measurement (0.536), representing the date when cyprids were most constrained nearshore, coincided with the high- 


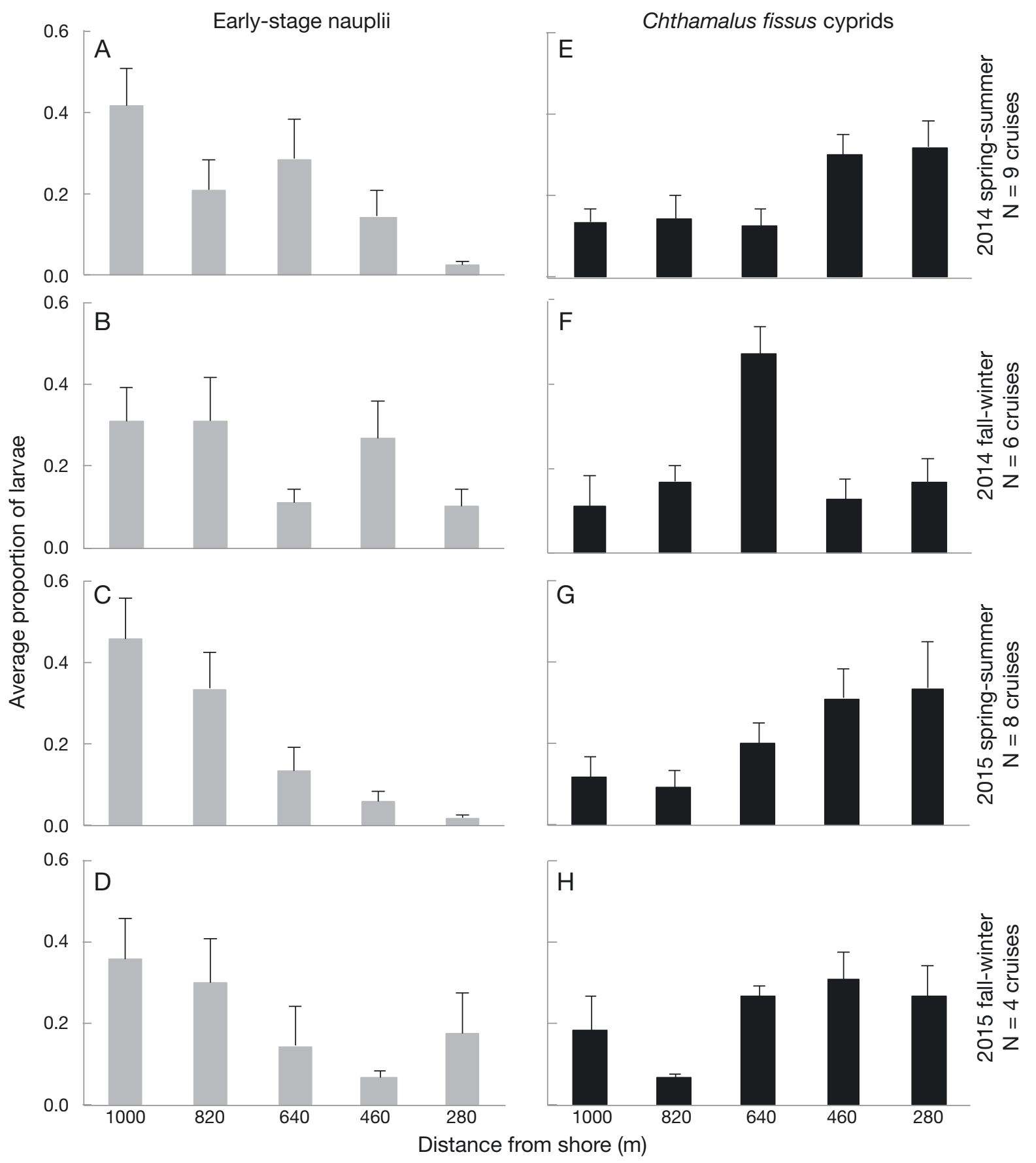

Fig. 7. Cross-shelf distributions of barnacle larvae. Average proportion of (A-D) total early-stage nauplii and (E-H) Chthamalus fissus cyprids present at each of the 5 stations during sampling periods (spring-summer versus fall-winter) by year (2014 versus 2015)

est zonal stratification $\left(0.505^{\circ} \mathrm{C} \mathrm{m}^{-1}\right)$. Average zonal stratification had a significant negative relationship with MDS and a significant positive relationship with the CDI for C. fissus cyprids (Fig. 9), but was not a significant predictor of early-stage nauplii $\mathrm{MDS}\left(\mathrm{R}^{2}=\right.$ $0.024, \mathrm{p}=0.521$ ).

\section{Summary of larval distribution patterns}

To summarize the 2014-2015 average barnacle larval distribution patterns, MDDs of $C$. fissus cyprids were deeper than those of early-stage nauplii, and MDD values increased with water depth and dis- 
Table 4. Results of 2-factor ANOVAs testing for differences in proportions of earlystage nauplii and Chthamalus fissus cyprids among stations and between sampling periods. Significant differences $(\alpha=0.05)$ are indicated in bold and post hoc test results are shown (stations represented by their distances from shore) for group pairs with significant differences

\begin{tabular}{|c|c|c|c|}
\hline Factor & $F$ & $\mathrm{p}$ & Post hoc test results \\
\hline \multicolumn{4}{|c|}{ Early-stage nauplii $(\mathrm{df}=1,115)$} \\
\hline Station & 26.210 & $<0.00001$ & $\begin{array}{r}1000 \mathrm{~m}>280 \mathrm{~m}, 1000 \mathrm{~m}>460 \mathrm{~m} \\
820 \mathrm{~m}>280 \mathrm{~m}, 640 \mathrm{~m}>280 \mathrm{~m}\end{array}$ \\
\hline Period & 0.775 & 0.380 & \\
\hline Station $\times$ Period & 1.534 & 0.218 & \\
\hline \multicolumn{4}{|c|}{ Chthamalus fissus cyprids ( $\mathrm{df}=1,105)$} \\
\hline Station & 20.907 & $<0.0001$ & $\begin{array}{r}280 \mathrm{~m}>1000 \mathrm{~m}, 280 \mathrm{~m}>820 \mathrm{~m} \\
460 \mathrm{~m}>1000 \mathrm{~m}, 460 \mathrm{~m}>820 \mathrm{~m}\end{array}$ \\
\hline Period & 0.102 & 0.749 & \\
\hline Station $\times$ Period & 5.704 & 0.018 & $\begin{array}{l}640 \mathrm{~m} \text { fall-winter }>640 \mathrm{~m} \text { spring- } \\
\operatorname{summer}\left(F_{1,22}=18.247, \mathbf{p}<\mathbf{0 . 0 0 1}\right)\end{array}$ \\
\hline
\end{tabular}

tance from shore for both larval stages (Fig. 6E). Densities of nauplii increased with distance from shore (Fig. 10A) while densities of cyprids were higher nearshore (Fig. 10B), and nauplii were much more abundant than cyprids (Fig. 10A,B). The majority of nauplii were found in plankton samples from offshore stations at a mid- to nearbottom depth (Fig. 10C,E), while the majority of cyprids were in samples from inshore stations at near-bottom depths (Fig. 10D,F).

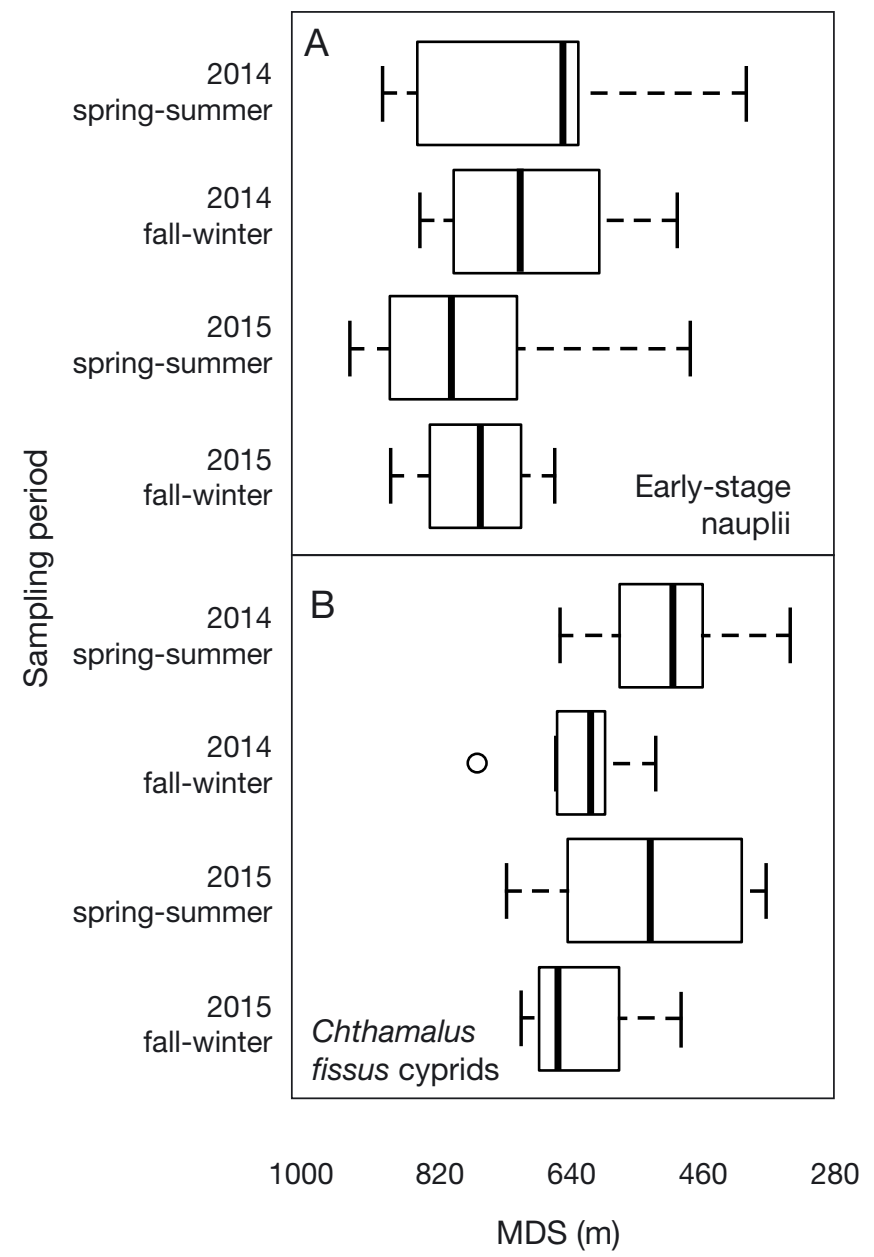

Fig. 8. Mean distance from shore (MDS) patterns of (A) early-stage nauplii and (B) Chthamalus fissus cyprids by sampling period and year. Lower and upper box limits are the first and third quartile, respectively, and box midline is median. Whiskers extend up to $1.5 \times$ the interquartile range to the farthest data point within that distance. Any data beyond that are shown individually as outlying points
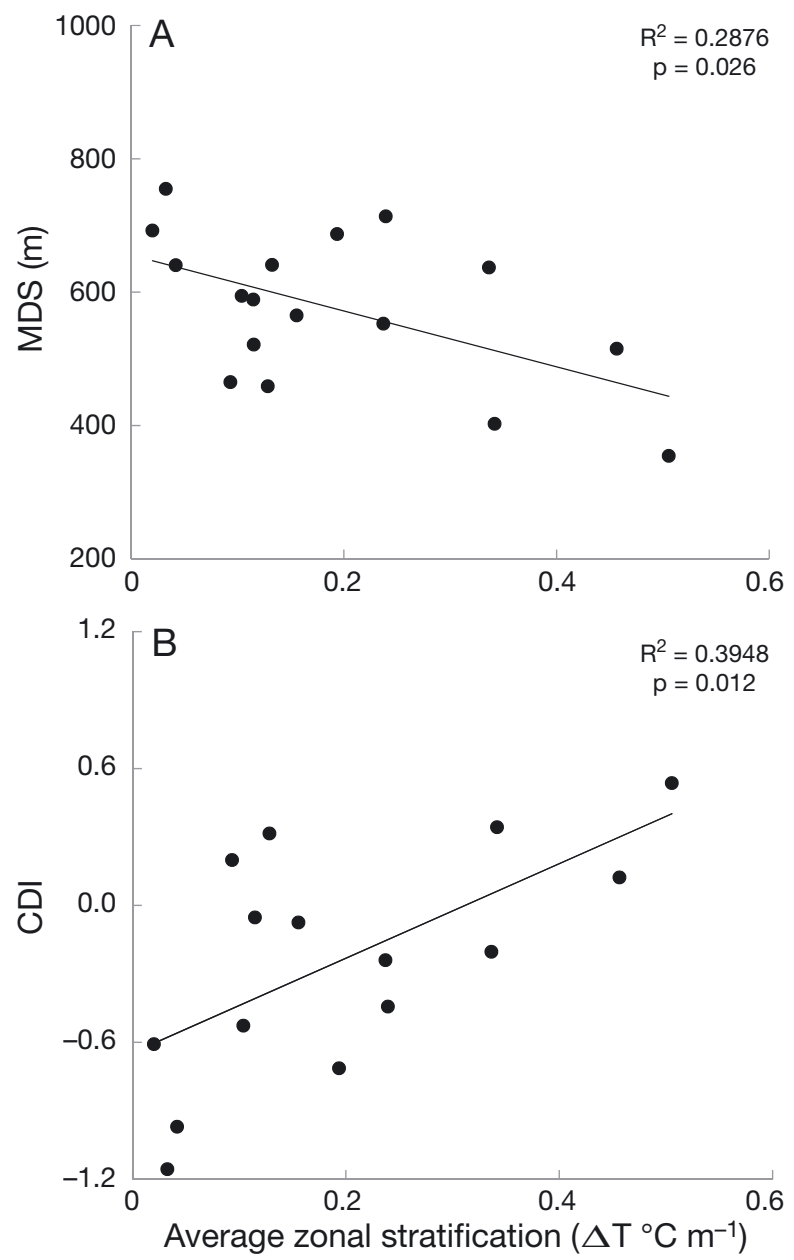

Fig. 9. Effect of zonal thermal stratification (average thermal stratification at stations 640,820 , and $1000 \mathrm{~m}$ from shore with bottom depths of 8,10 , and $12 \mathrm{~m}$, respectively) on Chthamalus fissus cyprid (A) mean distance from shore (MDS) and (B) constrained-distribution index (CDI). CDI was calculated for cruise dates when all 5 stations were sampled. Only 15 data points are shown because no C. fissus cyprids were collected on 2 of the 17 cruise dates 

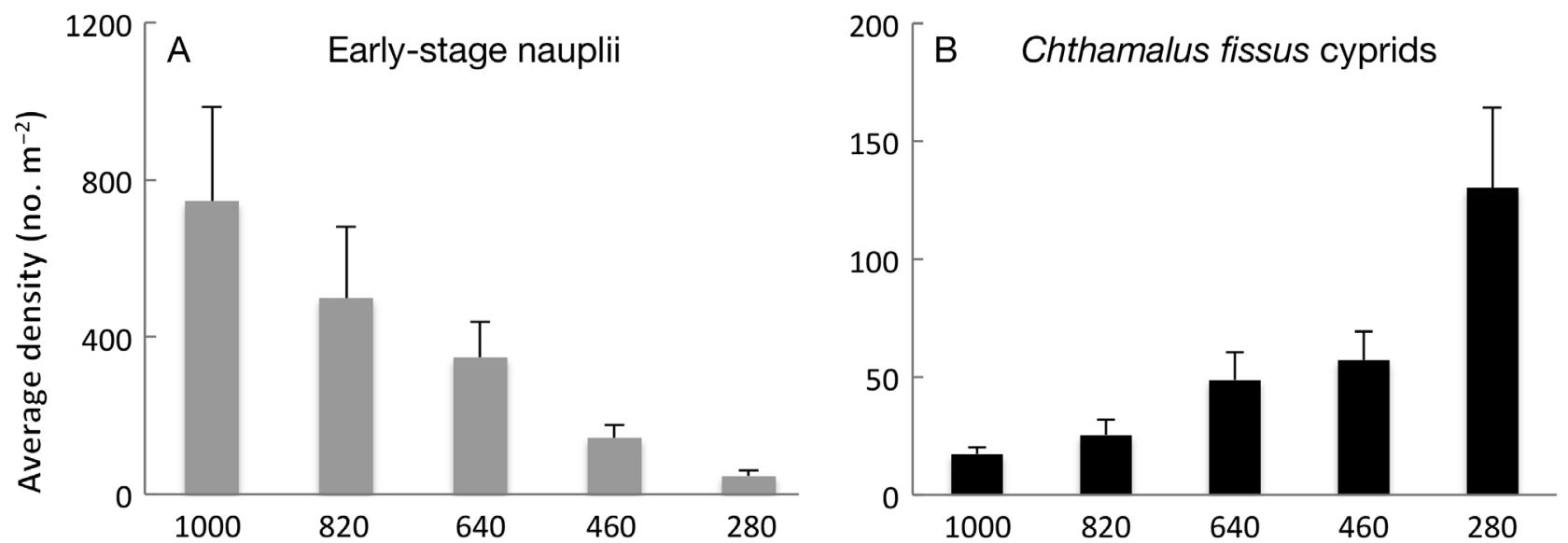

Distance from shore $(\mathrm{m})$

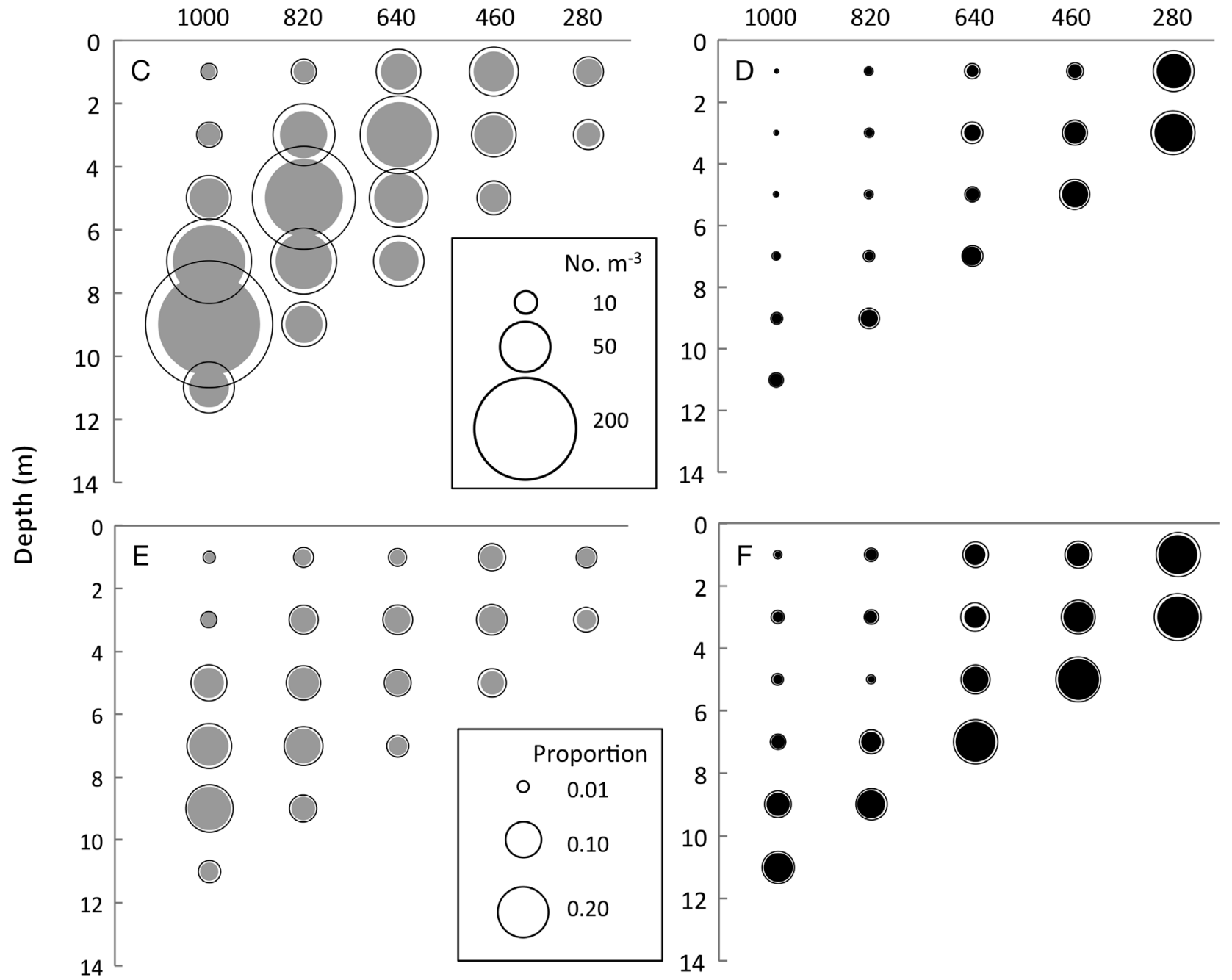

Fig. 10. Mean distributions for 2014 and 2015 ( $N=27$ cruises): overall cross-shore distribution patterns, showing average densities of (A) early-stage nauplii and (B) Chthamalus fissus cyprids at each station; average concentrations of (C) early-stage nauplii and (D) C. fissus cyprids in each plankton sample; and average proportions of (E) early-stage nauplii and (F) C. fissus cyprids in each plankton sample. Open circles surrounding the shaded averages represent SE 


\section{DISCUSSION}

Although larval concentrations varied from being high in 2014 spring-summer, decreased in 2014 fall-winter, and remained low through 2015 springsummer until increasing in 2015 fall-winter, vertical and cross-shelf distribution patterns of early-stage nauplii and Chthamalus fissus cyprids remained consistent despite significant seasonal and interannual variability. Mean larval concentrations decreased 2-fold for early-stage nauplii and 5-fold for C. fissus cyprids from 2014 to 2015, likely due to large-scale disturbances associated with a warm water anomaly commonly referred to as 'the Blob,' as well as El Niño conditions. Coastal sea surface temperatures in southern California began to warm as a result of 'the Blob' in mid-2014, after the start of our sampling regime, and remained anomalously warm until spring in 2015 (Leising et al. 2015). El Niño impacted southern California starting in spring 2015 and intensified in fall-winter of 2015, corresponding to the highest temperatures recorded at our site, lowest larval abundances, and the peak of the southern California coastal warm anomaly (Leising et al. 2015, Gentemann et al. 2017). Decreased larval abundances in 2015 could be associated with environmental conditions that may have increased larval mortality or offshore advection, diminished onshore larval transport, decreased adult reproduction, or a combination of these factors.

Early-stage nauplii abundances were considerably larger than those of cyprids, likely reflecting loss due to larval mortality or advection (Rumrill 1990, Tapia \& Pineda 2007), and the potential species diversity of early-stage nauplii. In contrast, concentrations of cyprids were higher than those of late-stage nauplii during all sampling periods throughout the $2 \mathrm{yr}$ study, suggesting that late-stage nauplii are advected farther offshore $(>1 \mathrm{~km})$ than our station located $1000 \mathrm{~m}$ from shore (12 $\mathrm{m}$ depth) before transitioning to the cyprid stage and returning to the intertidal. It is important to note that when sampling began in spring-summer of 2014, an additional station farther offshore at a $14 \mathrm{~m}$ depth was sampled during the first 3 cruises. This station was abandoned for the remainder of cruises due to plankton pump issues, but the mean density of late-stage nauplii (C. fissus and other species) at that station was $18.06( \pm 10.04) \mathrm{m}^{-2}$, while the mean density of late-stage nauplii in samples from all other stations was $1.22( \pm 0.73) \mathrm{m}^{-2}$, supporting previously observed patterns of early-stage nauplii closer to shore and later stages farther offshore (Tapia \& Pineda 2007, Morgan et al. 2009).
Vertical distributions of early-stage nauplii and $C$. fissus cyprids moved deeper with increasing depth and distance from shore, suggesting that the larvae were tracking bottom depth. Cyprids were deeper than nauplii (as in Shanks \& Shearman 2009, Tapia et al. 2010, Bonicelli et al. 2016), which could be due to the negative buoyancy of cyprids. Cyprids have been found at near-bottom depths (Barnett \& Jahn 1987, Pineda 1991, Bonicelli et al. 2016); non-feeding cyprids may seek deeper, cooler waters to lower their metabolic rate, thus maintaining storage reserves and remaining competent longer before finding a suitable place to settle. Cyprid larvae, however, have also been observed in surface waters (Le Fèvre \& Bourget 1991), sometimes associated with transient internal bore warm fronts (Pineda 1999). The pattern of cyprids deeper than nauplii was not as clear in 2015 as in 2014, and may be due to low larval abundance in 2015. Nauplii have been observed near the surface (Tapia et al. 2010), as well as in upper to middle depths of the water column (Bonicelli et al. 2016) and middle to bottom depths (Shanks \& Shearman 2009, Morgan \& Fisher 2010). However, early-stage nauplii (stages II and III, $~ 300 \mu \mathrm{m}$ maximum dimension for most species sampled) passed through the net used by Morgan \& Fisher (2010) (mesh aperture $335 \mu \mathrm{m})$ and the surface net used by Shanks \& Shearman (2009) (mesh aperture $330 \mu \mathrm{m})$. Further, all of these previous studies were conducted in deeper water using coarser sampling intervals (ranging from 5 to $30 \mathrm{~m}$, in contrast to our $2 \mathrm{~m}$ depth intervals). The majority of early-stage nauplii from our study were located at middle depths, but it cannot be discounted that later-stage nauplii assume a more surfaceoriented distribution as they move farther offshore than our research area. Additionally, vertical distribution is likely to be species-specific (Le Fèvre \& Bourget 1991, Morgan \& Fisher 2010, Bonicelli et al. 2016), but this cannot be discerned here.

Larval depth distributions were not related to the mid-depth of the thermocline or station-specific thermal stratification, suggesting that there is no temperature effect on vertical distribution. The MDD of early-stage nauplii was shallower when $\mathrm{SWH}$ was higher, which could be a result of specific naupliar behaviors including an upward shift in swimming direction and increased swimming rate (Yule 1984) in response to increasing pressure.

Cross-shore distribution patterns varied with larval stage: early-stage nauplii densities increased and $C$. fissus cyprid densities decreased with distance from shore. These distribution patterns were generally more distinct in spring-summer, when thermal strati- 
fication was strongest, than in fall-winter. As zonal stratification increased, the CDI increased, indicating that there were higher abundances of cyprids nearshore when zonal stratification was stronger. This relationship is further exemplified by the effect of decreasing cyprid MDS values with increasing zonal stratification. These results provide evidence that cyprids are constrained closer to shore when zonal stratification is higher, and are farther offshore when the water column is more well mixed. Higher stratification may enhance the behavioral control of horizontal distribution by allowing cyprids to exploit vertically sheared flows. Our results also indicate larger variability across depth of the cross-shore currents with increasing zonal stratification; such variability is expected to increase when currents are going in opposite directions, or when currents go in one direction, but magnitude changes with depth. Additionally, these findings could be related to shoreward transport of cyprids by the internal tide, motions that require water column stratification (Pineda 1999, Pfaff et al. 2015). When the water column is stratified and the internal tide occurs, cyprids could be transported from offshore waters to near our station $280 \mathrm{~m}$ from shore (4 m depth) where stratification weakens. Our findings explain the results of Pineda \& López (2002) that changes in thermal stratification are positively correlated with changes in barnacle settlement.

Our results indicate that larval densities and distributions were not directly related to alongshore or cross-shore current velocities. However, when zonal stratification increased, cross-shore currents were more variable and energetic throughout the water column and cyprids were closer to shore, suggesting that stratification can mediate cross-shore currents, and thus larval distributions. Given that current measurements from an ADCP located between the 8 and $10 \mathrm{~m}$ stations may not accurately reflect currents throughout our site due to small-scale variability at the nearshore (reviewed by Lentz \& Fewings 2012), physical measures that better resolve such smallscale variability are needed in the nearshore to resolve possible larval transport mechanisms.

In summary, distribution patterns of barnacle larvae within $1 \mathrm{~km}$ of the coast of La Jolla, southern California, were upheld across 27 sampling cruises over a 2 yr period despite varying environmental conditions from 2 large-scale disturbances: the warm 'Blob' and El Niño. For cyprids, cross-shore patterns varied seasonally. Our results support the inference that behavior plays a substantial role in facilitating transport during pelagic larval stages. Cross-shore distributions of cyprids were related to zonal stratifi- cation, which correlated with greater variability in the cross-shore vertical currents, but SWH did not significantly affect spatial patterns. These results support the hypothesis that the more thermal stratification there is, the more behavioral control can be exerted by cyprids to accumulate closer to shore, and that stratification is an important determinant of the successful larval transport of cyprid larvae. Nearshore accumulation of cyprid larvae has been previously observed (dos Santos et al. 2007, Tapia \& Pineda 2007, Shanks \& Shearman 2009). We hypothesize that thermal stratification mediates constrained larval distributions in nearshore waters. Vertically, larvae might maintain their positioning in more stratified waters. We propose that zonal stratification allows the internal tide to propagate shoreward. Where stratification breaks down, likely due to surface wave mixing, larvae will accumulate. In our case, accumulation of cyprids occurred at our most inshore station (280 $\mathrm{m}$ from the coast and $4 \mathrm{~m}$ deep), where stratification was weak during both springsummer and fall-winter sampling periods. We hypothesize that higher stratification will allow larvae to better maintain more constrained distributions, both in the nearshore, and we expect settlement to be higher during these conditions (Pineda \& López 2002).

Acknowledgements. This material is based upon work supported by the National Science Foundation under grants OCE-1357290, OCE-1357327, OCE-1630459, and OCE1630474. Support was also provided by the University of San Diego and Woods Hole Oceanographic Institution. We thank Anthony Basilio, Chris Bayne, Diana Fontaine, Colin Gaylord, Kate Hargenrader, Jamie Irving, Meredith Meyers, and Steven Searcy for their instrumental help with field collections and sample processing. Jennifer Prairie, Steven Lentz, and 3 anonymous reviewers provided valuable feedback on earlier drafts of the manuscript.

\section{LITERATURE CITED}

Barnett AM, Jahn AE (1987) Pattern and persistence of a nearshore planktonic ecosystem off southern California. Cont Shelf Res 7:1-25

Bonicelli J, Tyburczy J, Tapia FJ, Finke GR and others (2016) Diel vertical migration and cross-shore distribution of barnacle and bivalve larvae in the central Chile innershelf. J Exp Mar Biol Ecol 485:35-46

Branscomb ES, Vedder K (1982) A description of the naupliar stages of the barnacles Balanus glandula Darwin, Balanus cariosus Pallas, and Balanus crenatus Bruguière (Cirripedia, Thoracica). Crustaceana 42:83-95

Brown SK, Roughgarden J (1985) Growth, morphology, and laboratory culture of larvae of Balanus glandula (Cirripedia: Thoracica). J Crustac Biol 5:574-590

* Butler MJ IV, Paris CB, Goldstein JS, Matsuda H, Cowen RK 
(2011) Behavior constrains the dispersal of long-lived spiny lobster larvae. Mar Ecol Prog Ser 422:223-237

Cowen RK, Gawarkiewicz G, Pineda J, Thorrold SR, Werner FE (2007) Population connectivity in marine systems: an overview. Oceanography 20:14-21

Daigle RM, Metaxas A (2011) Vertical distribution of marine invertebrate larvae in response to thermal stratification in the laboratory. J Exp Mar Biol Ecol 409:89-98

Davies JL (1977) Geographical variation in coastal development. Longman, London

DiBacco C, Fuchs HL, Pineda J, Helfrich K (2011) Swimming behavior and velocities of barnacle cyprids in a downwelling flume. Mar Ecol Prog Ser 433:131-148

dos Santos A, Santos AMP, Conway DVP (2007) Horizontal and vertical distribution of cirripede cyprid larvae in an upwelling system off the Portuguese coast. Mar Ecol Prog Ser 329:145-155

Epifanio CE, Cohen JH (2016) Behavioral adaptations in larvae of brachyuran crabs: a review. J Exp Mar Biol Ecol 482:85-105

Gentemann CL, Fewings MR, García-Reyes M (2017) Satellite sea surface temperatures along the West Coast of the United States during the 2014-2016 northeast Pacific marine heat wave. Geophys Res Lett 44:312-319

Hagerty ML (2017) Vertical and cross-shore distributions of barnacle larvae in La Jolla, CA nearshore waters: implications for larval transport processes. MSc thesis, University of San Diego

Hines AH (1976) Comparative reproductive ecology of three species of intertidal barnacles. PhD dissertation, University of California, Berkeley, CA

Hines AH (1978) Reproduction in three species of intertidal barnacles from central California. Biol Bull (Woods Hole) 154:262-281

* Hoffman DL (1989) Settlement and recruitment patterns of a pedunculate barnacle, Pollicipes polymerus Sowerby, off La Jolla, California. J Exp Mar Biol Ecol 125:83-98

Jeffery CJ, Underwood AJ (2000) Consistent spatial patterns of arrival of larvae of the honeycomb barnacle Chamaesipho tasmanica Foster and Anderson in New South Wales. J Exp Mar Biol Ecol 252:109-127

* Le Fèvre J, Bourget E (1991) Neustonic niche for cirripede larvae as a possible adaptation to long-range dispersal. Mar Ecol Prog Ser 74:185-194

Leising AW, Schroeder ID, Bograd SJ, Abell J and others (2015) State of the California Current 2014-15: impacts of the warm-water 'Blob'. Calif Coop Ocean Fish Invest Rep $56: 31-68$

Lentz SJ, Fewings MR (2012) The wind- and wave- driven inner-shelf circulation. Annu Rev Mar Sci 4:317-343

* Lewis C (1975) Development of the gooseneck barnacle Pollicipes polymerus (Cirripedia: Lepadomorpha): fertilization through settlement. Mar Biol 32:141-153

Lloyd MJ, Metaxas A, deYoung B (2012) Patterns in vertical distribution and their potential effects on transport of larval benthic invertebrates in a shallow embayment. Mar Ecol Prog Ser 469:37-52

Metaxas A (2001) Behaviour in flow: perspectives on the distribution and dispersion of meroplanktonic larvae in the water column. Can J Fish Aquat Sci 58:86-98

Miller KM, Roughgarden J (1994) Descriptions of the larvae of Tetraclita rubescens and Megabalanus californicus with a comparison of the common barnacle larvae of the central California coast. J Crustac Biol 14:579-600

Miller KM, Blower SM, Hedgecock D, Roughgarden J (1989)
Comparison of larval and adult stages of Chthamalus dalli and Chthamalus fissus (Cirripedia: Thoracica). J Crustac Biol 9:242-256

* Morgan SG, Fisher JL (2010) Larval behavior regulates nearshore retention and offshore migration in an upwelling shadow and along the open coast. Mar Ecol Prog Ser 404:109-126

* Morgan SG, Fisher JL, Miller SH, McAfee ST, Largier JL (2009) Nearshore larval retention in a region of strong upwelling and recruitment limitation. Ecology 90: 3489-3502

* Palacios DM, Bograd SJ, Mendelssohn R, Schwing FB (2004) Long term and seasonal trends in stratification in the California Current, 1950-1993. J Geophys Res 109: C10016

* Paris CB, Cowen RK (2004) Direct evidence of a biophysical retention mechanism for coral reef fish larvae. Limnol Oceanogr 49:1964-1979

* Pfaff MC, Branch GM, Fisher JL, Hoffmann V, Ellis AG, Largier JL (2015) Delivery of marine larvae to shore requires multiple sequential transport mechanisms. Ecology 96:1399-1410

*Pineda J (1991) Predictable upwelling and the shoreward transport of planktonic larvae by internal tidal bores. Science 253:548-551

*Pineda J (1994) Spatial and temporal patterns in barnacle settlement rate along a southern California rocky shore. Mar Ecol Prog Ser 107:125-138

* Pineda J (1999) Circulation and larval distribution in internal tidal bore warm fronts. Limnol Oceanogr 44: 1400-1414

*Pineda J, López M (2002) Temperature, stratification and barnacle larval settlement in two Californian sites. Cont Shelf Res 22:1183-1198

Pineda J, Reyns N (2018) Larval transport in the coastal zone: biological and physical processes. In: Carrier TJ, Reitzel AM, Heyland A (eds) Evolutionary ecology of marine invertebrate larvae. Oxford University Press, New York, NY, p 141-159

* Rumrill SS (1990) Natural mortality of marine invertebrate larvae. Ophelia 32:163-198

* Ryan J, Harvey J, Zhang Y, Woodson C (2014) Distributions of invertebrate larvae and phytoplankton in a coastal upwelling system retention zone and peripheral front. J Exp Mar Biol Ecol 459:51-60

Shanks AL (ed) (2001) An identification guide to the larval marine invertebrates of the Pacific Northwest. Oregon State University Press, Corvallis, OR

* Shanks AL, Shearman RK (2009) Paradigm lost? Cross-shelf distributions of intertidal invertebrate larvae are unaffected by upwelling or downwelling. Mar Ecol Prog Ser 385:189-204

* Shanks AL, Grantham BA, Carr MH (2003) Propagule dispersal distance and the size and spacing of marine reserves. Ecol Appl 13(Suppl):S159-S169

* Shanks AL, Morgan SG, MacMahan J, Reniers AJ (2010) Surf zone physical and morphological regime as determinants of temporal and spatial variation in larval recruitment. J Exp Mar Biol Ecol 392:140-150

* Tapia FJ, Pineda J (2007) Stage-specific distribution of barnacle larvae in nearshore waters: potential for limited dispersal and high mortality rates. Mar Ecol Prog Ser 342:177-190

*Tapia FJ, DiBacco C, Jarrett J, Pineda J (2010) Vertical distribution of barnacle larvae at a fixed nearshore station in 
southern California: stage-specific and diel patterns. Estuar Coast Shelf Sci 86:265-270

Tremblay MJ, Sinclair M (1990) Sea scallop larvae Placopecten magellanicus on Georges Bank: vertical distribution in relation to water column stratification and food. Mar Ecol Prog Ser 61:1-15

Walley LJ, Rees E (1969) Studies on the larval structure and metamorphosis of Balanus balanoides (L.). Philos Trans R Soc B 256:237-280

Editorial responsibility: Pei-Yuan Qian, Kowloon, Hong Kong SAR
Weidberg N, Porri F, Von der Meden CEO, Jackson JM, Goschen W, McQuaid CD (2015) Mechanisms of nearshore retention and offshore export of mussel larvae over the Agulhas Bank. J Mar Syst 144:70-80

Winant CD, Bratkovich A (1981) Temperature and currents in the southern California shelf: a description of the variability. J Phys Oceanogr 11:71-86

Yule A (1984) The effect of temperature on the swimming activity of barnacle nauplii. Mar Biol Lett 5:1-11

Submitted: October 23, 2017; Accepted: March 12, 2018

Proofs received from author(s): April 30, 2018 